\title{
Iowa and the Centennial Exhibition of 1876
}

Homer L. Calkin

THE UNITED STATES CONGRESS ENACTED A LAW ON MARCH 3,1871 , authorizing an international exhibition of the "Arts, Manufactures, and Products of the Soil and Mine" in the city of Philadelphia in 1876 to commemorate one hundred years of American independence. Within one year each governor was to nominate a commissioner and an alternate to be appointed by President U. S. Grant to the Centennial Commission. This commission was instructed by law "to prepare and superintend the execution of a plan for holding the exhibition." 1 Within a few months the governor of Iowa, Samuel Merrill, nominated Robert Lowry, a state senator from Davenport, as Iowa's commissioner. Merrill named an alternate, Coker F. Clarkson of Eldora, after Secretary of State Hamilton Fish reminded him on November 18,1871 that no substitute had been nominated as required by law. ${ }^{2}$

When the commission convened at Philadelphia on March 4,1872 , Lowry immediately assumed a place of leadership. At the first meeting he was chosen chairman of the Committee on Credentials, and two days later he was elected fifth vice president of the commission. Subsequently, Lowry also became chairman of the Horticulture and Floriculture Committee. Clarkson was on the Fisheries and Fish Culture Committee.

'U.S. Statutes at Large, 16:470-1.

${ }^{2} J o u r n a l$ of the Proceedings of the United States Centennial Commission at Philadelphia, 1872 (Philadelphia, 1872), p. 26; Hamilton Fish to Governor [Merrill], November 18, 1871, Correspondence of the Centennial Exposition, Philadelphia, Iowa State Historical Department, Division of Historical Museum and Archives, Des Moines (hereafter cited as CCEP). 
Both men served on the commission until the end of the exhibition. ${ }^{3}$

During its first three sessions in 1872 the commission selected a site for the exhibition (Fairmont Park), made plans for the various buildings, decided upon the arrangement and classification of the objects to be displayed, planned for participation by foreign countries, and handled many other matters relating to the early planning for an exhibition.

At a meeting on May 29, a number of the commissioners voiced support for the success of the centennial celebration. Lowry was among those who spoke. He said in part:

I have the honor to represent the Hawkeye State, the young giant of the West. . . She is only twenty-six years old; has a population of one million three hundred thousand; has as handsome women, as energetic men, as healthy a climate, as rich a soil, and as cheap homes as any other State in the Union. We are marching on in greatness and prosperity, plowing up virgin soil, building school-houses and churches, and, you may rest assured, bound to do our best to make this centennial successful. ${ }^{4}$

It was not easy, however, to make the exhibition the success that Lowry had anticipated. It came down to one word"finances." The original Congressional act had provided no funds, but on June 1, 1872, Congress established a Board of Finance to raise funds to erect buildings on the exhibition grounds. The Board consisted of four members at large from each state and two from each Congressional district-a total of twenty-six from Iowa. The board members were to sell ten dollar shares of capital stock with each state being given a quota to raise in this manner. Iowa's quota of the ten million to be raised was $\$ 309,670$, the eleventh largest of the forty seven states and terrritories. ${ }^{5}$

Before many of the shares could be sold, the depression of

${ }^{3}$ Journal of Proceedings, pp; 18, 38; U.S. Centennial Commission, International Exhibition, 1876, Reports and Awards, edited by Francis A. Walker (Washington, D.C., 1880), II: 113-115. Lowry said he attended every regular meeting of the Commission from the first on March 4, 1872 to the final one on Jan. 15, 1879. Lowry to Governor John H. Grier, July 16, 1879, CCEP.

4 Journal of Proceedings, 153-154.

SJournal of Proceedings, App. 1, p. 18; U.S. Statutes at Large, 17:203-211. 
1873 spread throughout the nation and cut back on the number of shares people were willing and able to buy. Lowry, in writing to Governor Cyrus C. Carpenter in January 1874, said, "What amount of stock the people of Iowa have taken we do not know, but are apprehensive that it is as yet very little. We do hope that at least part of Iowa's quota will be taken." ${ }^{6}$ In fact, Iowans bought a total of only seven shares and paid only $\$ 66$ to the fund.?

Yet Lowry was concerned that Iowa do its best to make the Centennial a success. In December 1873 he urged Carpenter to "allude to the Centennial Exhibition in as strong a manner as possible" when addressing the general assembly. Lowry was

very anxious that Iowa will be thoroughly represented in the rich products of her soil, mine, and manufacture. . . . I do not want to see her represented by a large Pumkin [sic] and five bushell [sic] of Potatoes. But I want to see her there in all her pride and and glory. ${ }^{8}$

Lowry recommended that immediate steps be taken to organize a board of centennial managers and establish a central office from which to disseminate information to potential exhibitors. ${ }^{9}$

Governor Carpenter, in his biennial message to the general assembly, said he regarded "it as highly important that Iowa should make a creditable exhibition ... in this great World's Fair." A few days later, in a special message, the governor sent Lowry's letter and other documents to the Assembly. He urged that the members of the legislature take whatever action they considered wise. He also recommended that at least enough money be appropriated for the expenses of Lowry and Clarkson. ${ }^{10}$

At least one state official opposed any such action. N. B. Baker, adjutant general, wrote the governor that he did "not CCEP.

'Lowry to Governor C. C. Carpenter (signed also by Coker Clarkson). [January 1874],

'Philadelphia Inquirer, November 11, 1876.

'Lowry to Carpenter, December 13, 1873, CCEP.

'Lowry to Carpenter, [January 1874], CCEP.

${ }^{10}$ Reports and Awards, vol. II, App. D, pp. 138-143. 
believe in the project of borrowing so many thousands of dollars." Instead, he suggested that Justice William E. Miller, because he was well known, could collect all that was needed for the exhibition. Publicity on the Centennial Exhibition failed to arouse much interest in Iowa at this time, and the 1874 general assembly adjourned without taking any action in support of the project, either in appropriating money or authorizing a board of managers.

Lowry urged Carpenter to proceed with naming "five good practical men who would find and take an interest in the matter." If future legislatures would not pay their expenses, "they must pay their own, and charge it to patriotism." Capenter appointed such a board, with S. H. Mallory of Chariton as president and R. V. Ankeny of Des Moines as treasurer. ${ }^{11}$ The Iowa Board of Centennial Managers, as it was named, subsequently drew up a plan for showing Iowa's growth and progress. It appointed one person for each of the thirty-seven classes of exhibits to select samples of "everything grown, manufactured or dug from the bowels of the earth" and prepare them for shipment. To do this, funds were needed, but the legislature had appropriated none. An assessment was made, therefore, upon the whole state at the rate of approximately one cent for each inhabitant. This amounted to $\$ 11,904$. Circulars were issued, and appeals were made to the press and individuals for help.

Ankeny advertised for six active agents to canvass along the several railroad lines in behalf of the commission to raise money. An appeal to the Chicago, Rock Island and Pacific Railroad, however, failed to bring free transportation for this purpose. Hugh Riddle, General Superintendent of the company, was willing to grant free transportation to take Iowa's products and manufactured articles to Philadelphia in 1876, but he did "not feel at liberty" to provide free rides for the

"Lowry to Carpenter, March 27 and April 17, 1874, CCEP. Other officers were N. B. Baker of Des Moines, Vice President, and Alexander Shaw of Des Moines, Secretary. The Executive Committee was John G. Foote of Burlington and Buren B. Sherman and Baker of Des Moines. Managers were Joshua M. Shaffer of Keokuk and A. F. Tipton of Elkader. 
commissioners "engaged in the work of soliciting and arranging for the exhibit." Fares had already been reduced, and "our lines do not pay the cost of operating", he wrote. ${ }^{12}$

When all responses to these appeals became so faint they could hardly be heard, the board turned to the women-and to them belongs the credit for getting the project underway. Mrs. C. A. Wheeler was appointed as agent to solicit subscriptions, and Mrs. Emily F. Ives was later employed as agent by the board. Some counties were not able to raise enough money to pay the ladies' railroad and other expenses, while others went greatly beyond their quotas.

Concerts, exhibitions, personal solicitations, and even tea parties were employed as fund-raising activities. The "tea parties" began in late 1875 and continued into the next year. By the first of December the ladies of Sigourney had raised $\$ 122.45$ toward the quota of $\$ 194$ for Keokuk County. A "determined opposition from some of Johnny Bull's lineal descendants was manifested," but this reportedly "had a tendency to increase rather than diminish the gross receipts." ${ }^{13}$ At a tea party held during the middle of December the ladies of Burlington cleared $\$ 320$. The tea parties in Council Bluffs, Pella, and Dubuque were typical of many. In Council Bluffs the party consisted of supper, tableaux, music, and a recitationall for the price of fifty cents. Without question it was a success, and netted approximately $\$ 300$-enough to meet the county's quota of $\$ 168$, leaving about $\$ 100$ for the Y.M.C.A. library after payment of all debts. The Pella tea party was held on February 10 at the Opera House which was decorated with festoons of evergreens intertwined with flowers, patriotic mottoes in blue and gold, portraits of national leaders of the Revolutionary period, and the national colors. The program opened with music, a prayer and brief address by the Reverend Dr. Dunn. The remainder of the program consisted of a series of readings, tableaux and music. The gross receipts

${ }^{12}$ Iowa State Register (Des Moines), September 4, 1874; Hugh Riddle, Chicago to Carpenter, October 30, 1874, CCEP.

'3J. A. Donnell, Sigourney, to Carpenter, December 6, 1875, CCEP. 
were $\$ 115$, leaving nearly $\$ 100$ for the Centennial fund. ${ }^{14}$

By mid-February Dubuque County had not raised its apportionment of $\$ 390$. The editor of the Dubuque Daily Times wrote on February 17: "We are pleased to note the fact that the Centennial fire has once more been kindled in Dubuque." He had been somewhat ashamed of Dubuque's conduct and for several weeks could not mention the word "Centennial" without blushing. "Now we can shout it from the house tops, proclaim it from the custom house steps, vociferate it from the shot tower . . . and bring it before the council." A "grand tea party," including a supper, tableaux, music, short speeches and dancing, was to be held at Turner Hall. The Dubuque Daily Times joked that a great many Dubuquers had been accustomed to "drinking tea there for some time, out of glass mugs." Flags, shields, banners, bannerets and appropriate evergreen devices decorated the Hall-"the effect being greatly enriched by the ancient and fancy costumes of the local "76-ers." Many kinds of tea-oolong, gunpowder, old hyson and the strong black variety-were served. Sandwiches, doughnuts, biscuits, baked beans, cakes, pies and numerous other foods were available. Two military companies, the Rifles and the Guards, added to the splendor of the occasion, and the Great Western Band furnished the music. Another scheme to raise money for the Centennial was selling memberships for $\$ 1$. In return one would receive a certificate-a picture designed and engraved by C. A. Johnson of Des Moines. It was a composite of seventeen sketches representing Iowa and America in 1776 and 1876. At the top was a large seal of Iowa, surmounted by an eagle and surrounded by flags.

In November 1875 General James S. Brisbin of the Board of Finance had urged Governor Carpenter to hold a state convention to publicize the Centennial. Brisbin wrote that, "It is time Iowa was moving in this matter and I know of no better way to do it." He said he would be "glad to come and address" the convention. A "Centennial Military Convention” was held 
on December 22 at the Des Moines Opera House. In the absence of Carpenter because of illness in his family, A. Newton, Mayor of Des Moines, presided. Hiram Thomas showed "illuminated views" of the "Centennial palaces." Brisbin, in his speech, noted that Iowa was not one of the states that had voted money in support of the exhibition. He urged that some action be taken.

Governor Carpenter made one last appeal, before leaving office, for support of Iowa's showing at Philadelphia. He recommended that "immediate and effective steps be taken by the legislature to assure proper representation at the Centennial."

In a message to the General Assembly twelve days later, the new Governor, Samuel J. Kirkwood, recommended an appropriation that would "enable those who may be charged with procuring and exhibiting the products of Iowa, to do so in a plain, economical, but proper manner." Since the growth of Iowa in population and wealth, for many years to come, would depend largely upon immigration, he thought,

A creditable showing at the Centennial Exhibition of the capabilities of our State may do much to bring immigrants among us, and our failure in that regard may work us injury. Aside from this consideration, a proper degree of State pride should lead us to make sure that such of our citizens as may visit the exhibition shall not have cause to feel ashamed of the position our State will occupy there. ${ }^{15}$

The Iowa legislature finally appropriated $\$ 20,000$ on February 16,1876 , to aid in "exhibiting the resources, industries, and products of the State of Iowa." The Executive Council was to be responsible for spending the money in the best interests of the state. ${ }^{16}$

Meanwhile many Iowans were busy preparing exhibits and arousing enthusiasm for the Philadelphia Exhibition. Mary B.

${ }^{15}$ Messages and Proclamations of the Governors of Iowa, ed. by Benjamin Shambaugh (lowa City, 1903-1905) IV:306-307.

${ }^{16}$ Reports and Awards, vol. II, app. D, pp. 142-143. The Executive Council consisted of S. J. Kirkwood, Governor, Alexander Shaw of Des Moines, William Christy, State Treasurer, B.

R. Sherman and I. T. Young. 
Welch, wife of the president of Iowa Agricultural College, noted that the ladies of Dubuque, Burlington, Grinnell and Davenport were being asked to furnish examples of their "fancy and needle work." Through the zeal of Mrs. Waldo M. Potter a society had been formed in Davenport to collect the articles. When the exhibition closed, the articles were to be returned and sold for the benefit of the Davenport Scientific Association.

The Centennial department at the fair of the Polk County Agricultural Society, under the management of Mrs. Ives and Mrs. Fred S. Dunham of Monticello, was the center of attraction for a large crowd. The approach of the nation's hundredth birthday added interest-especially in the relics being shown. These included a fan carried at Washington's inaugural ball, brass candlesticks, continental money issued in 1777 and other items, some dating back as much as 250 years. Prof. Macomber of the Agricultural College showed one sample of an exhibit of Iowa soils he would be taking to Philadelphia. Samples of wax casts of Iowa apples, painted by Mrs. William Greenland, were also being shown at the Polk County fair.

The two hundred teachers who attended a meeting of the State Teachers Association at Burlington in December 1875 agreed to have Iowa schools represented at the Centennial. Shortly after this, Alonzo Abernethy, Superintendent of Public Instruction, published a pamphlet outlining the materials that should be prepared for Philadelphia. These included plans and photographs of school buildings; collections of reports, catalogs, courses of study, and brief histories of all institutions; and exercises in printing, penmanship, composition and mapping.

In March 1876 State Treasurer William Christy was sent to Philadelphia to contract for the erection of the Iowa headquarters building. Upon his return to Des Moines he reported that Iowa was to have no space in the main exhibition building. Because of the delay by the General Assembly in appropriating money, Iowa lagged behind other states in erecting a 
headquarters building. In spite of this the Iowa building was fairly well located, between the Missouri and Tennessee buildings, about one-quarter of a mile from the main exhibition building. It was a two-storey building, forty-eight by forty feet. The lower floor consisted of two offices and two reception rooms; the rooms on the upper floor were used as sleeping quarters for those in charge of Iowa's exhibits.

Once the exhibition was open to the public, Iowans visited their home state's displays in substantial numbers. By the middle of June more than 2,000 had attended, and by September 3 the Iowa building had been visited by more than 7,000 Iowans. On Iowa Day, September 7, C. C. Nourse of Des Moines delivered an address at the Judges' Pavilion. Before a large crowd, about 200 of whom were from Iowa, he boasted: "Iowa is capable of sustaining a people equal to the present population of the entire nation." ${ }^{17}$

The efforts of the Iowans responsible for getting a display together had been successful. In April the Executive Council announced that exhibitors could ship their articles to be shown at Philadelphia free of charge. By April 16 at least 60,000 pounds of goods had been shipped from Des Moines, Keokuk, Burlington, Davenport, Clinton and Dubuque to Philadelphia. Certain exhibits, such as the fresh fruits and vegetables and livestock, were shipped in September in time for judging. More than ninety individuals, companies, associations and state organizations sent exhibits of varying kinds. The fertility and productiveness of Iowa's soil, the inventive genius of her citizens, and the character and extent of the state's manufactures were to be judged by these articles shown in Philadelphia. Of these exhibits, nearly half received awards.

Judges for the Centennial were selected from the United States and foreign countries. Two Iowans were among those first chosen in May-E. H. Williams of Clayton County and J. M. Shaffer of Keokuk. Both declined. Through the efforts of

${ }^{17}$ Register, March 19, July 13, 1876, September 8, 1876. 


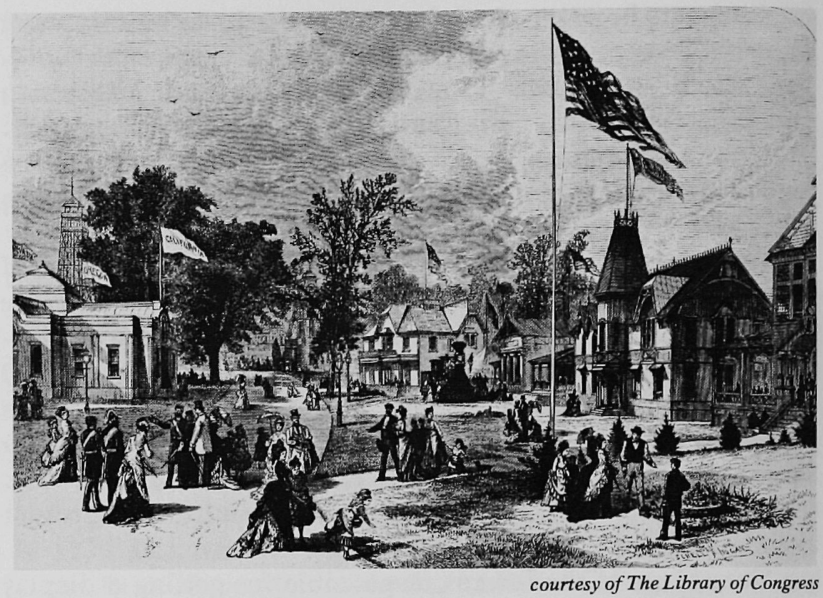

$A$ view of the Centennial Exhibition in Philadelphia, 1876.

Lowry five other judges from Iowa were appointed later. These were Milo Smith of Clinton, judging horses; O. H. Buchanan of Mt. Pleasant, sheep; Z. C. Luse of Iowa City, poultry; and George L. Davenport of Davenport and Suel Foster of Muscatine, pomology.

The exhibition afforded an opportunity for Iowa, and individuals from the state, to advertise. This was especially true of those who had inventions they had patented within the past two or three years. For instance, two model railroad cars fourteen inches long, eight inches wide and seven inches high were exhibited. The cars were designed to show the working of a "link guide and pin puller," a car coupling device patented by S. A. Wolcott and G. Wernimont of the Chicago, Dubuque and Minnesota Railroad. The invention did away with all risks in connecting and disconnecting railway cars. The model was sent to the American Master Mechanics Railroad Association in Philadelphia for their inspection and then to the Centennial. ${ }^{18}$ 
Another Iowa invention that received an award was the brick stamping machine of Isaac H. Garretson of Keokuk. It was simple, and the one exhibited in Philadelphia quite crude in construction. A machine with two stampers cost $\$ 100$, within the reach of people with limited means. Garretson stated that six stampers would make 18,000 bricks in ten hours. ${ }^{19}$

The judges gave Edwin W. Brady of Davenport an award for his window shades which were commended for their durability and method of construction, providing both shade and ventilation. Other awards were given to the Murray Iron Works of Burlington for their meat cutters and to A. H. Woodruff for his gear for locomotive engines. ${ }^{20}$ As might be expected from an agricultural state, several manufacturing companies displayed farm implements. However, only one, the Skinner Brothers of Des Moines, won an award; that was for their plows. ${ }^{21}$

According to one observer, only two or three of Iowa's exhibits in the Machinery Hall were "particularly worthy of notice." The judges apparently agreed because only Sample, McElroy and Company and S. S. Vail, both of Keokuk, received awards. One was for a semi-portable steam engine and boiler, and the other a reversible steam boiler.

Although Iowa had been a state for only thirty years, the educational exhibit prepared by Abernethy was greatly admired. The judges, in their report, said the exhibited work which came from Burlington, Davenport and Des Moines, as

${ }^{19}$ Reports and Awards, III:186-7, IV:750.

${ }^{20}$ Iowa State Register, October 14,1876 . Among the other inventors who had exhibits but did not receive awards were: T. S. Buck and Co., Davenport, rubber type forms and dating stamp; Frank G. Noyes, Clinton, gang edger for four circular saws; Sol Kuh, Grand Junction, straw twister; Carl G. Buttkreit, Des Moines, upright bell piano; W. S. Garrison, Volga City, tubular heating stove; and C. Chamberlain, Dubuque, churn.

${ }^{21}$ Register, October 14, 1876. Others with exhibits were: Morrison Bros., Des Moines, self-cleaning plows; Orchard City Wagon Works, plows, hay rake and wagons; Wright Spring Co.lDenmark, wagon spring; Funck and Hertzler, Burlington, wagons; Eagle Manufacturing Co., Davenport, horse rake and cultivator; W. F. Pumphrey, Fairfield, seed mill and grain separator; S. J. Wallace, Keokuk, straddle row cultivator; S. S. Hitchcock, Des Moines, farm scales; T. C. Hanna, Keokuk, wheat dryer; J. Feender, Charles City, clod masher; and T. Kellog, MacGregor, wine mill. 
well as many smaller towns and rural districts, was characterized by "general excellence and neatness of mechanical execution." Awards were given to the State Department of Public Instruction and the boards of education of West Des Moines and Burlington. ${ }^{22}$

Other items displayed included two hundred specimens of handiwork "from the fair hands of our Iowa daughters," oatmeal, and wine. A. J. Shipman of State Center took two native English setters and won an award for them. One of the most unusual and interesting displays was an award-winning table made by Oren E. Miles of Oskaloosa. The table was made of ten varieties of Iowa wood, numbering 3,983 pieces, each piece, however small and delicate, going through the entire thickness of the table. The design of the table top consisted of twenty-four arrows, the points of the six largest forming a sixpointed star in the center. Six unstrung bows made the border. Miles was praised for the beauty of his design and his good workmanship.

Iowa made her best showing in exhibits relating to geology and mineralogy, the natural resources of the state, and agricultural products. In the mineral annex to the Main Exhibition Building Iowa had a collection of her mineral and geological wealth, "which is said to be one of the finest" in the exhibition. William Fox had arranged a unique exhibit in twelve glass-front, black walnut cases which showed the geological stratification by specimens of the various formations to the depth of 3,700 feet. It covered the state from the Potsdam sandstone near McGregor to the Drift deposit near Council Bluffs. John Harvey and Scribe Harris collected more than a ton of lead ore from the mines near Dubuque. The lead was of outstanding richness, containing ninety percent pure lead. J. W. Bishop of Keokuk was in charge of the coal exhibit. Wesley Redhead of Des Moines sent a six foot vertical sample, weighing one ton, of his "Black Diamonds". The Mahaska

${ }^{22}$ Reports and Awards, VIII:31-2, 317; Register, October 14, 1876. The smaller towns included Atlantic, Muscatine, Ottumwa, Marengo, Boone, Sigourney, Winterset, Lyons, Indianola, Wheatland, Clarence and Osceola. 
County Coal Company sent a two ton sample. Awards were given for these exhibits of geological specimens, lead and coal.

Donahue and McCosh of Burlington had charge of collecting fifty-five varieties of building stone from all sections of the state. Each sample was nine by twelve inches, being cut on all sides except one, to show samples of tool work with one surface left to show the natural appearance in the quarry. Professor Macomber and Dr. Shaw collected sands, gravel, clays, gypsum and ochres that were used for buildings and mouldings. Most came from Polk County while the Fort Dodge area furnished some glass sands. Neither display won an award. Macomber and Shaw were also responsible for an exhibit of soil from thirty-five counties. A vertical section of soil was shown in large glass tubes six feet long and six inches in diameter. Affixed to each cylinder was a map of Iowa on which a small green spot indicated the county from which the soil was taken.

These soils were of interest to nearly all visitors. Since it was the only display of its kind-there was nothing comparable from any other state-it attracted a great deal of attention. The Swedish Centennial commissioners selected one of the tubes to be forwarded to Sweden as a sample of the agricultural area where so many Swedes had found a home.

A number of award-winning exhibits showed products of Iowa's rich soil. These occupied 1566 square feet of space in the Agricultural Hall, the largest amount of any state. H. H. McAfee, of Iowa State Agricultural College and Secretary of the American Forestry Association, prepared specimens of more than 160 varieties of wood. Each specimen consisted of a cross section of wood and a vertical section twice the diameter. One specimen of cottonwood was $6 \frac{1 / 2}{2}$ in diameter. In addition there were seventy-five varieties of timber seeds. Joseph Fulton, a farmer from Jefferson County, prepared on behalf of the state an extensive exhibit of 500 varieties of seeds, grasses and grains. Of these, 292 were in bottles ranging from four ounces to a half gallon in size. The remaining 
varieties were in the stock or in the sheaf. The display of corn was outstanding. It was shown in the stock and was planted weekly from the last week in April to the first week in July. The yield of the first planting was 120 bushels to the acre. One stock was nineteen feet high and twenty-seven ears of corn filled a bushel basket. In addition to the award to the state for its large collection, H. C. Jordan of Eldon received one for his yellow field corn, one ear of which weighed one pound, thirteen ounces. It is interesting to learn that the Empress Thereza, wife of Emperor Dom Pedro II of Brazil, was so impressed by Iowa corn when she saw it that she asked for some ears to take home with her.

Three other individual awards should be noted. L. J. Clute of Manchester received an award for his "meritorious collection" of twenty-five varieties of potatoes, and W. W. Winterbotham of Fort Madison was commended for his timothy seed. J. C. Arthur of Charles City had prepared an herbarium of about 1500 specimens of Iowa flowering plants. In fact, he had two collections-one classified, neatly labeled and mounted for those interested in the scientific identification of the plants and the other for those with a more general interest.

Livestock and dairy products also had a place at the exhibition. John Stewart of Manchester not only exhibited his creamery butter but also shipped about 8000 pounds a week to Philadelphia to be sold for $\$ 2500$ to $\$ 3000$. In competition with nearly thirty others from some of the famous butter regions of the United States, Stewart won the Dairy Association's gold medal for best samples of 200 pounds and thirtyfive pounds. In addition he received an award for an exhibit of samples of creamery butter from several different creameries. He was commended for the "clean, sweet flavor and firm texture" and general "superior excellence of the butter."

On August 16 members of the Iowa Fine Stock Association met at West Liberty to select herds to be shown at the Centennial. They chose merino sheep, Berkshire hogs and Poland China hogs, none of which were to be winners.

Four awards were given to Iowans for cattle. Baron 
French, the bull shown by Eli Elliott of West Liberty, was "entitled to rank as a superior specimen" because of "his form, quality, and useful characteristics." S. W. Jacobs and E. Wilson and Son, also of West Liberty, were commended for the cows they showed. The animals shown by Wilson included a cow, Emma Downe, and a heifer calf, Centennial Minnie, born on the Centennial grounds. A herd of one bull and four cows, shown by the State Association, was ranked as first class specimens of the breed.

Surprisingly, it was in pomology that Iowa made her most remarkable showing. After weeks of preparation, the wax casts of fruit were ready to be taken to Philadelphia. One person wrote that "the closest examination fails to reveal any difference between the natural fruit and the fac simile until the samples are weighed." The wax casts were placed on a table thirty feet by seven feet, each variety-there were 308 of apples alone-under a separate vase, each marked in gilt letters with the name of the particular variety. Many who saw the wax casts would not believe that they were true representations of fruit grown in Iowa. This, of course, was disproved by later events when Iowa received ten percent of the awards given to American exhibitors.

As the time neared for the judging of fruits in September, Iowans were told that they could make a splendid showing if the horticulturalists would only make up their minds in time to make the needed preparations. The exhibit "should be so complete and well arranged as will disabuse the minds of any who have the mistaken idea that Iowa cannot raise choice fruit."

When the fresh fruits arrived, the collection was large and impressive. It consisted of 1541 plates, containing 342 varieties of apples; 161 plates, fifty varieties of pears; twelve varieties of plums; ten of grapes; and two of quinces. Iowa exceeded the space allotted to her and asked for more. When it was displayed, the exhibit extended across the center from one end of the hall to the other and nearly across again in a second row. G. B. Brackett, general superintendent of the Pomological Hall, had secured a "capital location" for Iowa. A single pear 
that occupied a plate by itself weighed twenty-two ounces. The Iowa Horticultural Society received an award for a very creditable exhibit of 140 plates of pears which were "generally very well grown and finely colored." Others who received awards for their pears were Wilson T. Smith of Des Moines, G. B. Brackett of Denmark, and G. L. Hilton, John Geirn and the White Elk Vineyard of Keokuk. The judges commented in their report that these pears were of "superior size and beauty, very well grown, very choice specimens, and of very brilliant coloring."

Polk County received an award for the large number of varieties of apples-165-it exhibited and for the superior manner in which they had been grown. The judges also commented on the great care and correctness that had been observed in naming the varieties. Individual awards for exhibits of apples went to Henry Avery, David Leonard, W. W. Gearheart and E. H. Calkins of Burlington, Z. Hollingsworth of Montrose and R. S. Willett of Malcom. The State Horticultural Society received an award for the wax models which were "of perfect accuracy, and beautifully displayed." In fact, the judges were not the only ones who were impressed by these wax casts. Two hundred of them were obtained by the Japanese Centennial Commission to be sent to Japan following the Exhibition.

After the Centennial Exhibition was over, it was announced that the soils, stone and coal from Iowa had been awarded a place in the main building in Philadelphia which would become a perpetual exposition. Other articles were returned to Des Moines.

The editor of the Register summed up the accomplishments of Iowa at the Centennial by saying that no one need be ashamed of the position Iowa "held among the other States. Many of our citizens have done nobly in their efforts to have our interests fairly represented." Although the non-activity of the Iowa legislature of 1873-74 had delayed preparations for the Centennial Exhibition, the appropriation in 1876 "came in time to save our State from utter disgrace." 
Copyright of Annals of Iowa is the property of State of Iowa, by \& through the State Historical Society of Iowa and its content may not be copied or emailed to multiple sites or posted to a listserv without the copyright holder's express written permission. However, users may print, download, or email articles for individual use. 